\title{
CdS/CdTe Thin-Film Solar Cell with a Zinc Stannate Buffer Layer
}

X. Wu, P. Sheldon, Y. Mahathongdy, R. Ribelin, A. Mason, H.R. Moutinho, and T.J. Coutts National Renewable Energy Laboratory

Presented at the National Center for Photovoltaics Program Review Meeting Denver, Colorado

September 8-11, 1998

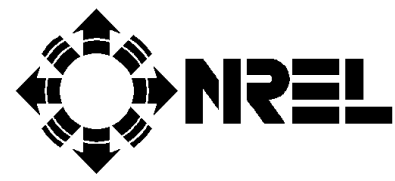

National Renewable Energy Laboratory 1617 Cole Boulevard

Golden, Colorado 80401-3393

A national laboratory of the U.S. Department of Energy Managed by Midwest Research Institute for the U.S. Department of Energy under contract No. DE-AC36-83CH10093

Work performed under task number PV904201

October 1998 


\section{NOTICE}

This report was prepared as an account of work sponsored by an agency of the United States government. Neither the United States government nor any agency thereof, nor any of their employees, makes any warranty, express or implied, or assumes any legal liability or responsibility for the accuracy, completeness, or usefulness of any information, apparatus, product, or process disclosed, or represents that its use would not infringe privately owned rights. Reference herein to any specific commercial product, process, or service by trade name, trademark, manufacturer, or otherwise does not necessarily constitute or imply its endorsement, recommendation, or favoring by the United States government or any agency thereof. The views and opinions of authors expressed herein do not necessarily state or reflect those of the United States government or any agency thereof.

Available to DOE and DOE contractors from:

Office of Scientific and Technical Information (OSTI)

P.O. Box 62

Oak Ridge, TN 37831

Prices available by calling 423-576-8401

Available to the public from:

National Technical Information Service (NTIS)

U.S. Department of Commerce

5285 Port Royal Road

Springfield, VA 22161

703-605-6000 or 800-553-6847

or

DOE Information Bridge

http://www.doe.gov/bridge/home.html 


\title{
CdS/CdTe Thin-Film Solar Cell with a Zinc Stannate Buffer Layer
}

\author{
X. Wu, P. Sheldon, Y. Mahathongdy, R. Ribelin, \\ A. Mason, H.R. Moutinho, and T.J. Coutts \\ National Renewable Energy Laboratory, Golden, Colorado 80401
}

\begin{abstract}
This paper describes an improved $\mathrm{CdS} / \mathrm{CdTe}$ polycrystalline thin-film solar-cell device structure that integrates a zinc stannate $\left(\mathrm{Zn}_{2} \mathrm{SnO}_{4}\right.$ or ZTO) buffer layer between the transparent conductive oxide (TCO) layer and the CdS window layer. Zinc stannate films have a high bandgap, high transmittance, low absorptance, and low surface roughness. In addition, these films are chemically stable and exhibit higher resistivities that are roughly matched to that of the CdS window layer in the device structure. Preliminary device results have demonstrated that by integrating a ZTO buffer layer in both $\mathrm{SnO}_{2}$-based and $\mathrm{Cd}_{2} \mathrm{SnO}_{4}$ (CTO)-based $\mathrm{CdS} / \mathrm{CdTe}$ devices, performance and reproducibility can be significantly enhanced.
\end{abstract}

Cadmium telluride has long been recognized as a promising photovoltaic material for thin-film solar cells because of its near optimum bandgap of $\sim 1.45 \mathrm{eV}$ and its high direct absorption coefficient. Small-area CdTe cells with efficiencies of greater than $15 \%$ (1) and CdTe modules with efficiencies of greater than 9\% (2) have been demonstrated. The field stability of CdTe modules has also been confirmed. One remaining challenge is to further improve device performance and reproducibility. In this paper, we report that by integrating a $\mathrm{Zn}_{2} \mathrm{SnO}_{4}$ buffer layer into $\mathrm{CdS} / \mathrm{CdTe}$ devices, performance and reproducibility can be significantly enhanced.

Performance and reproducibility of $\mathrm{CdS} / \mathrm{CdTe}$ devices can be impacted by many factors. For example, in heterojunction solar cells, it is well known that higher shortcircuit currents can be obtained by reducing the window-layer absorption. In $\mathrm{CdS} / \mathrm{CdTe}$ cells, this is achieved by reducing the CdS thickness to improve the blue spectral response. However, reducing the CdS layer thickness can adversely impact device opencircuit voltage $\left(\mathrm{V}_{\mathrm{oc}}\right)$. As the $\mathrm{CdS}$ thickness is thinned, the probability of pinhole formation increases, causing localized $\mathrm{TCO} / \mathrm{CdTe}$ junctions with inferior device parameters $\left(\mathrm{V}_{\mathrm{oc}}\right.$ and fill factor). Performance and reproducibility can also be affected by back-contact processing. Polycrystalline CdTe is very difficult to dope heavily p-type, and therefore, to make a low-resistance back-contact, a wet-chemical etch is typically used to form a $\mathrm{p}^{+}$surface region. Although this $\mathrm{p}^{+}$surface layer facilitates ohmic contact formation, this etch can also preferentially etch grain boundaries, leaving highly conductive shunt paths that degrade the device parameters. Finally, performance and reproducibility can be influenced by the $\mathrm{CdCl}_{2}$ anneal used by all cell manufacturers. The $\mathrm{CdCl}_{2}$ treatment is an important process for making high-efficiency CdTe devices and offers several substantial benefits such as: increased grain size, grain-boundary passivation, increased $\mathrm{CdS} / \mathrm{CdTe}$ interface alloying, and reduced lattice mismatch between the CdS and CdTe layers. However, one disadvantage of the $\mathrm{CdCh}_{2}$ treatment is that over-treatment can result in adhesion loss problems. Grain growth, which can occur 
during $\mathrm{CdCl}_{2}$ treatment, introduces stress at the interface between the $\mathrm{CdS}$ and $\mathrm{CTO}$ layer, resulting in film blistering or peeling.

The addition of a high-resistivity buffer layer, placed between the TCO and the CdS layers, could address the performance and reproducibility issues described above as follows: i) If the resistivity of the buffer layer were roughly matched to that of the $\mathrm{CdS}$ layer, the buffer layer could reduce the probability of forming localized TCO/CdTe junctions that can occur when the CdS layer is thinned. Thus, high $\mathrm{V}_{\text {oc }}$ could be maintained while reducing the $\mathrm{CdS}$ thickness to provide higher device short-circuit current density $\left(\mathrm{J}_{\mathrm{sc}}\right)$; ii) If the buffer layer were resistant to the etches used for backcontact formation (i.e., served as a "stop etch" layer), these devices would be less susceptible to over-etching, which could greatly reduce shunting problems; and iii) A buffer layer could help relieve stresses between these layers, thereby improving adhesion during the $\mathrm{CdCl}_{2}$ treatment. We have developed a ZTO buffer layer that, when integrated into a CdS/CdTe device structure, imparts all the above-mentioned benefits.

ZTO films were prepared by RF sputtering from a hot-pressed oxide target. The 2-in.diameter target was $\sim 60 \% \mathrm{Zn} /(\mathrm{Zn}+\mathrm{Sn})$, as determined by X-ray photoemission spectroscopic (XPS) measurements. ZTO films were deposited in pure $\mathrm{O}_{2}$ at room temperature. We find that ZTO films have properties that make them ideal as a buffer layer in $\mathrm{CdS} / \mathrm{CdTe}$ devices. They have low absorptance, are highly resistive, have low surface roughness, and are chemically stable. Figure 1 shows the transmittance, reflectance, and absorptance of a ZTO film. The films exhibit near-zero absorptance and have a wide optical bandgap $(\sim 3.3 \mathrm{eV})$. As-deposited ZTO films have resistivities of more than $1000-\mathrm{cm}$. The resistivity typically decreases to $0.1-10-\mathrm{cm}$ (which roughly matches that of the $\mathrm{CdS}$ window-layer resistivity) after annealing in an $\mathrm{Ar} / \mathrm{CdS}$ ambient for 5 minutes in a temperature range of $500^{\circ} \mathrm{C}$ to $600^{\circ} \mathrm{C}$. As-deposited, ZTO films are amorphous and crystallize into a single-phase spinel structure after thermal annealing. As shown in Figure 2: an atomic force micrograph of a typical ZTO film, these films have very smooth surfaces, with an average surface roughness of $\sim 20 \AA$. We also find that ZTO films are chemically stable and cannot be etched in $\mathrm{HCl}, \mathrm{HNO}_{3}$, or nitric/phosphoric-based acid etches.

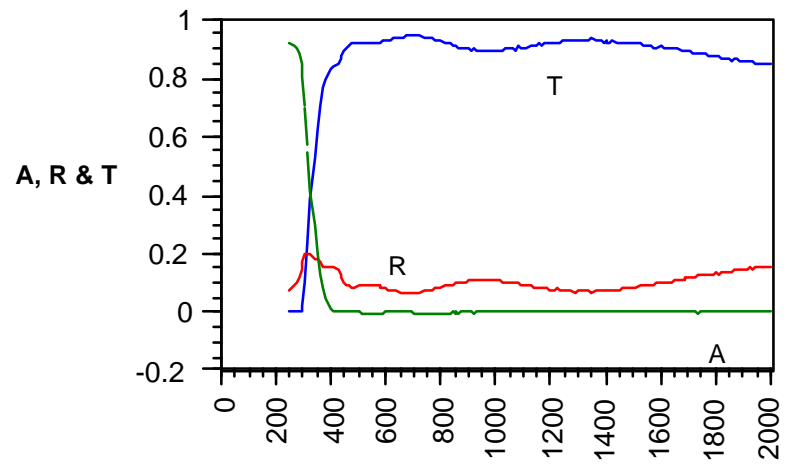

Wavelength $(\mathrm{nm})$

Figure 1. The transmittance, reflectance, and absorptance of a ZTO film. 


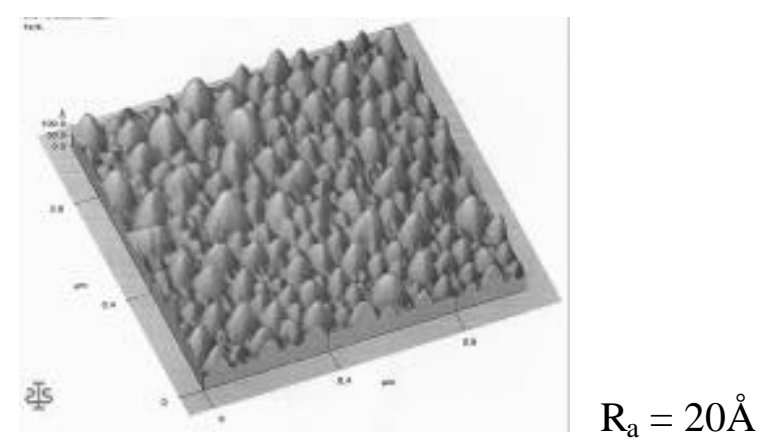

Figure 2. An atomic force micrograph of the surface of a ZTO film.

For the first time, we have fabricated CdTe devices with ZTO buffer layers. Figure 3 shows the modified CdS/CdTe device structure. Both $\mathrm{SnO}_{2}$ and $\mathrm{Cd}_{2} \mathrm{SnO}_{4}(3,4) \mathrm{TCO}$ films have been used in this work. Preliminary cell results have demonstrated that highperformance $\mathrm{CdS} / \mathrm{CdTe}$ devices can be fabricated by integrating a ZTO buffer layer into $\mathrm{CdS} / \mathrm{CdTe}$ devices. For example, a glass $/ \mathrm{Cd}_{2} \mathrm{SnO}_{4} / \mathrm{ZTO} / \mathrm{CdS} / \mathrm{CdTe}$ device with a $\sim 700 \AA$ $\mathrm{CdS}$ layer has been fabricated with a $\mathrm{J}_{\mathrm{sc}}$ of $24.8 \mathrm{~mA} / \mathrm{cm}^{2}$. Although the CdS is thin, this device retained a high $\mathrm{V}_{\mathrm{oc}}(816 \mathrm{mV})$ and fill factor $(72.6 \%)$ due to the addition of a ZTO buffer layer.

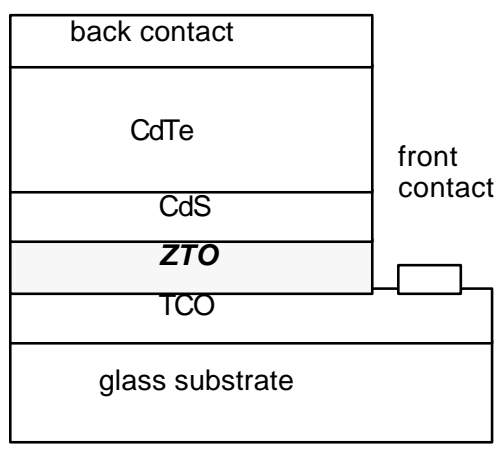

Figure 3. An improved CdS/CdTe device structure with a ZTO buffer layer.

Table 1 shows device parameters for two identically processed cells. Each of these devices uses an absorber layer that is thinner than we typically use in our standard device structure. Both devices were over-etched during back-contact formation. As shown in Table 1, the $\mathrm{V}_{\mathrm{oc}}$ and efficiency of a device without a ZTO buffer layer are only $679 \mathrm{mV}$ and $5.7 \%$, respectively. In contrast, the device with a ZTO buffer layer is able to maintain a high $\mathrm{V}_{\mathrm{oc}}(807 \mathrm{mV})$ and has a much higher efficiency $(12.8 \%)$. The improved device parameters are attributed to the ZTO buffer layer acting as a nonconductive stopetch layer, which reduces device shunting.

Table 1. Improved Thin CdTe Cell Performance

\begin{tabular}{|c|c|c|c|c|}
\hline Cell structure & $\begin{array}{c}\mathrm{V}_{\mathrm{oc}} \\
(\mathrm{mV})\end{array}$ & $\begin{array}{c}\mathrm{J}_{\mathrm{sc}} \\
\left(\mathrm{mA} / \mathrm{cm}^{2}\right)\end{array}$ & $\begin{array}{c}\text { FF } \\
(\%)\end{array}$ & $\begin{array}{c}\text { Eff. } \\
(\%)\end{array}$ \\
\hline CTO/CdS/CdTe & 679 & 19.0 & 44.2 & 5.7 \\
\hline CTO/ZTO/CdS/CdTe & 807 & 23.0 & 68.8 & 12.8 \\
\hline
\end{tabular}


We also find that integrating a ZTO buffer layer can significantly improve the adhesion after $\mathrm{CdCh}_{2}$ treatment. These results are summarized in Table 2, which shows a total of $98 \mathrm{CdS} / \mathrm{CdTe}$ devices, each of which received a $100 \%$ saturated $\mathrm{CdCb}$ solution soak (50\%-75\% $\mathrm{CdCl}_{2}$ solution is typical) and subsequent thermal anneal and was evaluated for adhesion. Eighty-four of these devices had the ZTO buffer layer integrated into the structure, and 14 did not. Without the buffer layer, under these extreme conditions, we found that one cell had good adhesion out of a total of 14 (7\% yield). In sharp contrast, with the ZTO buffer layer, 79 cells had good adhesion out of 84 (94\% yield). This result has significant manufacturing ramifications: The ZTO buffer layer provides far better adhesion, and thus, much greater process latitude when optimizing the $\mathrm{CdCl}$ process step.

Table 2. Significantly Improved Adhesion after $\mathrm{CdCb}$ Treatment

\begin{tabular}{|c|c|c|}
\hline & $\begin{array}{c}\text { CdTe cells without } \\
\text { ZTO layer }\end{array}$ & $\begin{array}{c}\text { CdTe cells with } \\
\text { ZTO layer }\end{array}$ \\
\hline Total & 14 & 84 \\
\hline Good adhesion & 1 & 79 \\
\hline Blister on edges & 8 & 5 \\
\hline Completely peeled off & 5 & 0 \\
\hline
\end{tabular}

Finally, we find that the addition of a ZTO buffer layer provides excellent device reproducibility. This is clearly seen in Figure 4, which shows the efficiency of 30 identically processed devices $\left(18 \mathrm{Cd}_{2} \mathrm{SnO}_{4}\right.$-based CdTe cells and $12 \mathrm{SnO}_{2}$-based $\mathrm{CdTe}$ cells), all of which included a ZTO buffer layer but did not have an antireflection coating to reduce reflection losses. This set of 30 devices had an average efficiency of $13.83 \%$, with a standard deviation of $0.375 \%$.

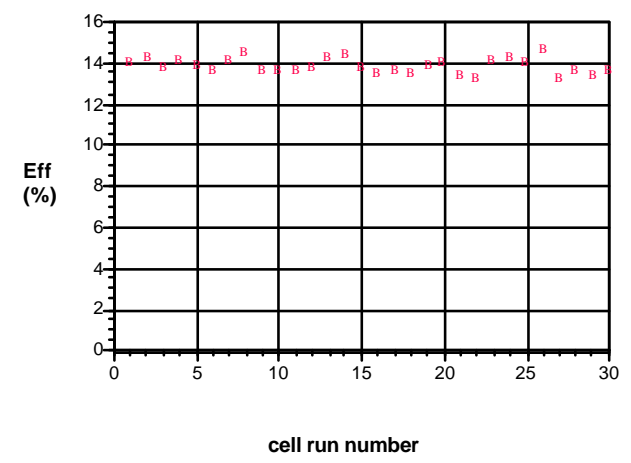

Figure 4. Performance and reproducibility of $\mathrm{CdS} / \mathrm{CdTe}$ solar cells with ZTO buffer layers.

By integrating a ZTO buffer layer into a CTO-based CdS/CdTe cell, we have achieved efficiencies as high as $15.0 \%$ as shown in figure 5 . Figure 5 shows the standard I-V curve of this cell. We believe that the performance of CdS/CdTe cells with the ZTO buffer layer is far from optimized and expect that improved understanding of the physics and 
chemistry of how ZTO buffer layers impact CdS/CdTe devices will lead to further enhancements in device performance.

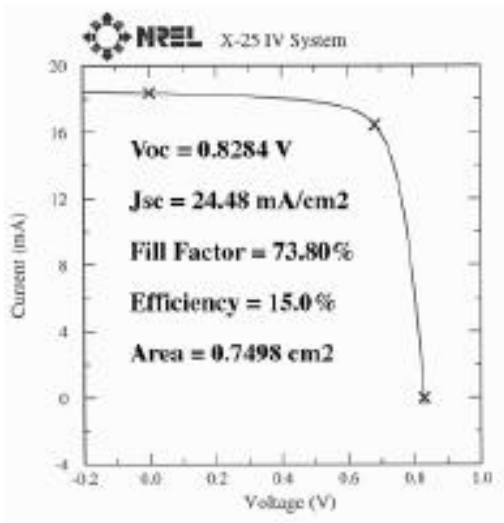

Figure 5. I-V curve of a $\mathrm{Cd}_{2} \mathrm{SnO}_{4}$-based $\mathrm{CdS} / \mathrm{CdTe}$ cell with a ZTO buffer layer.

The authors would like to thank H. Field and D. Dunlavy for standard I-V measurements. This work was supported by the U.S. Department of Energy under Contract No. DE-AC36-83CH10093.

(1) J. Britt and C. Ferekides, Appl. Phys. Lett. 62, 2851 (1993).

(2) K. Zweibel, H. Ullal, and B. von Roedern, 25 ${ }^{\text {th }}$ IEEE Photovoltaic Spec. Conf., 745 (1996).

(3) X. Wu, P. Sheldon, T. J. Coutts, D. H. Rose, W. P. Mulligan, and H. R. Moutinho, $14^{\text {th }}$ NREL/SNL Photovoltaics Program Review, 693 (1996).

(4) X. Wu, P. Sheldon, T. J. Coutts, D. H. Rose, and H. R. Moutinho, $26^{\text {th }}$ IEEE Photovoltaic Spec. Conf., 347 (1997). 